\title{
A Synopsis of Numerical Time Scales
}

1917-1986

\section{by Manfred Menning}

This review accompanies a multicoloured synoptic chart (inserted loose in this issue) comparing some 30 complete and partial geochronological time scales for the Phanerozoic and published over a 70 year period to 1986 . Provided for Episodes readers by the Central Institute for Physics of the Earth in Potsdam, East Germany, the chart illustrates the evolution of the geological time scale since the advent of radiometric dating. It is a salutary experience to see how close the most recent scales are to Barrell's 1917 estimates, and to gauge the extent of "fine-tuning" that has taken place since Arthur Holmes' 1959 scale. This chart provides a convenient companion to the 1989 IUGS Global Stratigraphic Chart, which will be circulated in a fortheoming issue of Episodes. (Ed.)

\section{Introduction}

Underlying many geological models and theories is the concept of time. Calculations of the rates of sedimentation and subsidence (Bubnoff, 1948; Menning, 1989), the periodicity of orogenesis (Stille, 1924), changes of global sea level (Vail and Mitchum, 1977) and climate, the velocity of radiation, evolution and extinction of animals, the mass-age distribution of Phanerozoic sediments (Gregor, 1985), and the evolution of isotope ratios (Burke et al., 1982) all depend on one geochronological time scale or another (see Benkö, 1985 , for a recent review of geological, geophysical and cosmogenic eycles). The present review and the accompanying synoptic chart (also being published in Zeitschrift für Geologische Wissenschaften, vol. 17, 1989) facilitate ready comparisons between these various time scales, and analysis of the trends in variation from one to another.

\section{The New Chart}

The synoptic chart presents the data as close as possible to the original versions (for Precambrian time see Cloud, 1987). However, the data are not directly comparable in all cases, in part because different workers derived them by different methods. Values judged by the original author as less reliable are given in the chart with a question mark or in smaller numbers, and the names on the chart reflect the original spelling. Most stratigraphic units are biostratigraphically defined, and some are of lithostratigraphic nature. Consequently, rather than using the term "chronostratigraphic" unit proposed by Hedberg (1976), they are referred to in the legend below the chart as "biostratigraphic" units, a term accepted by many European scientists.

Goodchild (1897, in Barrell, 1917) constructed an astonishingly suitable time scale, in which the base of the Cambrian, for example, was placed at $704 \mathrm{Ma}$. Following the discovery of the radionctive decay law by Rutherford and Soddy (1902-1903, in Kaemmel, 1986), Barrell (1917, p. 884-885) published the pioneer radiometric time seale. This was based on five isotope age determinations, their fixed place in the geological column, and interpolation of outstanding quality using relative thicknesses of strata. The ages given in column 1 of the synoptic chart are arithmetical means of Barcell's confidence limits for each system boundary. Barrell's scale was improved only in 1959 by Holmes whose earlier time scales $(1937,1947)$ were influenced by the dating of younger parts of polyphase mineralizations (e.g. at Joachimsthal, Czechoslovakia).
The first estimate of the duration of stages for the Devonian to Cretaceous periods was made by Harland and others (1964). For Mesozoic time they assumed comparable durations for each stage in a separate system. Armstrong (1978) recalculated the ages of the Palaeozoic and Vesozoic stages using the new IUGS decay constants (Steiger and Jäger, 1977). He favoured older dates because of the characteristic daughter product loss in many isotopic systems. Consequently, the age of the most pre-Cretaceous boundaries increased substantially. Armstrong did not publish digital data, so that the ages have to be derived from his Figure 2, which results in some inaccuracies. Likewise, the numerical numbers of Van Eysinga (1975) were taken from a wall chart. Columns 13 and 20 include data from several publications, which considered only part of Phanerozoic time and which are sometimes in disagreement.

The most widely used scales now are those from IGCP Project 196 (Odin, 1982a, b) and from Harland and others (1982), which differ significantly. The Geological Society of America time scale for DNAG (the Decade of North American Geology; Palmer, 1983), the interim time-seale of Snelling (1985b), which was not available for this synopsis, and the present author's own synthetic scale (Figs. 1,2) are in most parts compromises based on both Harland and colleagues and on Odin. Odin preferred glauconies for Mesozoic and Cenozoic times, and most of his boundaries were clearly younger than the tuff ages favoured by Harland and colleagues. Odin, for example, assumed a longer Lower (40 $\mathrm{Ma})$ and a shorter Upper Carboniferous $(30 \mathrm{Ma})$, relative to llarland's estimates of $27 \mathrm{Ma}$ for the former and $47 \mathrm{Ma}$ for the latter. The duration of the Silurian ( $18 \mathrm{Ma}$ ) was also underestimated by Odin (1982a, b). As to the base of the Phanerozoic, there is no agreement that the Cambrian starts with the Tommotian $(530 \mathrm{Ma})$ as argued by Odin and, in any case, Harland and others (1982) dated the lower boundary of the Cambrian at $590 \mathrm{Ha}$.

Palmer's (1983) numerical ages were prepared by the Time Scale Advisory Committee of DNAG, in which "all numerical ages except those for the upper and lower boundaries of the Palaeozoic are derived from Harland and others (1982)." The DNAG scale is more useful than the recent COSUNA ("Correlation of Stratigraphic Units of North America") scale (Salvador, 1985), in which pre-Cretaceous ages are rounded off to $5 \mathrm{Ma}$. However, biological evolution certainly does not follow such a regular pattern. Furthermore, Salvador's scale overestimates the duration of some stages, such as the Rhaetian, which contains only one or two ammonoid zones, in comparison with the Scythian, which contains eight to ten such zones. There is also no geological reason for the big difference on this scale between the Frasnian (5 . Ta) and the Famennian ( $15 \mathrm{Ma}$ ).

Carr and co-workers (1984) used a stepwise linear regression model. They calculated system boundaries only, because of insufficient biostratigraphic control on most series and stages. The synoptic chart gives the values from Carr's Table 3 , column $\mathrm{A}$, in which stages within each system are assigned equal durations. Their preference for $3 \pm 5$ Ma as the age of the base of the Quaternary is unrealistic, their 

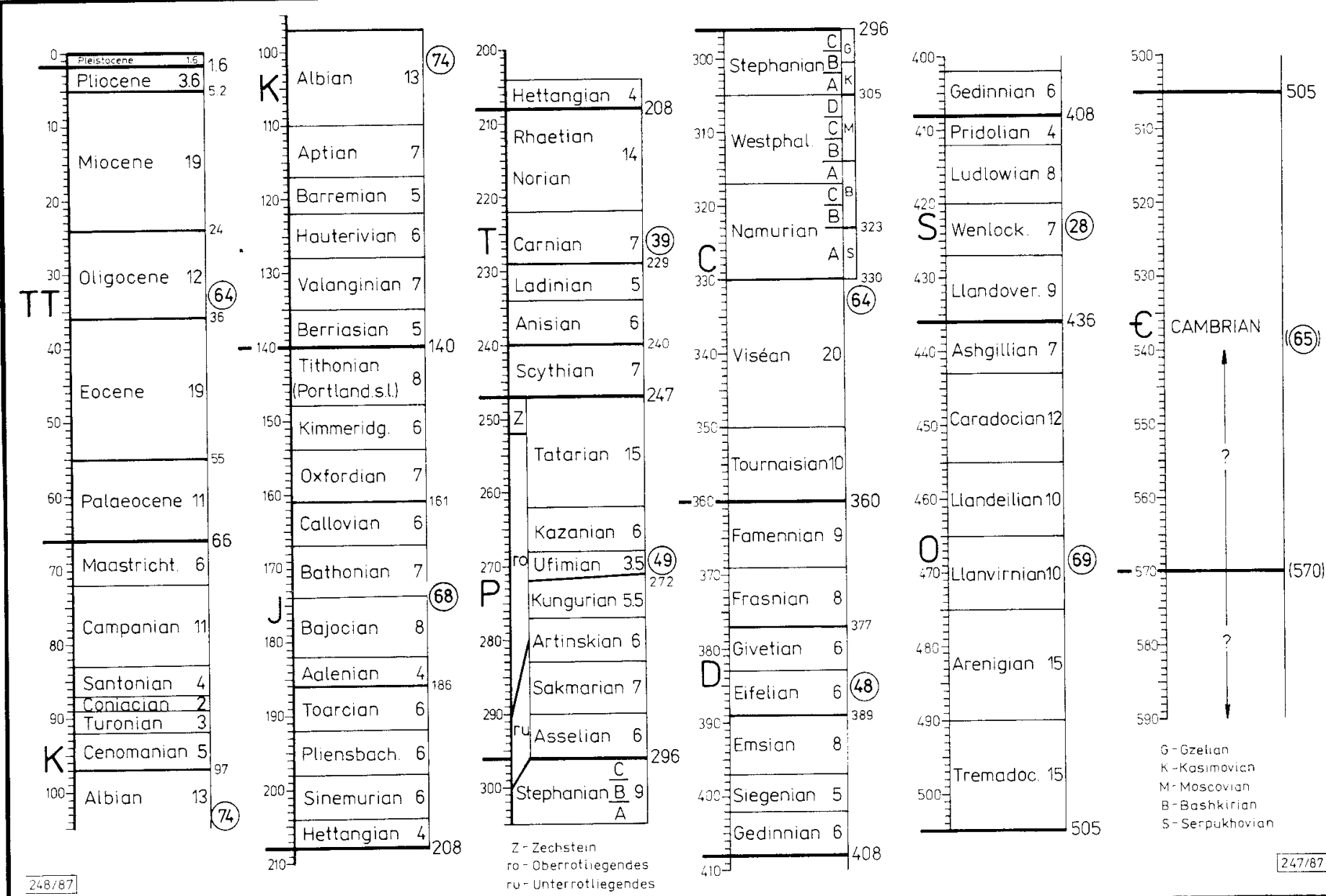

$247 / 87$

Figure 1: A new preliminary synoptic time scale

for use in central Europe. See text for explanation.

A New Time Scale for Central Europe

For practical purposes in Central Europe, a new preliminary synthetic time scale has been derived (Fig. 1) in cooperation with the biostratigraphers and lithostratigraphers listed in the Acknowledgements. For this we have used the synoptic chart, primary data, and various geological criteria. The most substantial revision concerns the Upper Carboniferous to Middle Triassic interval, based on a combination of intercontinental biostratigraphic (Dunbar and others, 1960, Kozur, 1980, Anderson, 1981) and magnetostratigraphic correlations (Menning, 1986), thicknesses (Likharev, 1966), and radiometric data (Forster and Warrington, 1985; Ilellmann and Lippolt, 1981; Hess and Lippolt, 1986; Lippolt, Hess and Burger, 1984; Webb, 1981). An updated and revised version of this approach will be published in Schriftenreihe Geologische Wissenschaften (Akademie-Verlag Berlin).

What is needed is a time scale compiled under the auspices of the IUGS Commission on Stratigraphy through interdisciplinary cooperation of specialists in biostratigraphy, lithostratigraphy, isotope-geochronometry, magnetostratigraphy and others with regard to typical thicknesses on platforms, stratigraphic completeness and condensation, number of bio-units, weighted radiometric data, wellfounded intercontinental correlations by different methods, and the dating of new minerals (e.g. sylvinite - Pilot and Rösler, 1967). To do this, agreed stratotypes (Cowie et al., 1986) as well as a stable nomenclature (Jaeger, 1980) will have to be established. The application of an improved mathematical algorithm alone (Carr et al., 1984, Bayer 1987) will not solve the calibration problems.

Acknowledgements: I thank Drs. G. Beutler and F. Schuiler (Potsdam), W. Ernst (Greifswald), H. Jaeger, E. Kahlert and E. Schulz (Berlin), B. Schröder (Bochum), K.-Ar. 'Iröger 
(Freiberg) and D. Weyer (Magdeburg) for fertile discussions and guides to the literature. I am especially grateful to E. Schröder for initial literature information and to H. Kämpf for continuously encouraging me to delve deeper into time analysis. I thank my colleagues at Potsdam, P. Bankwitz and G. Schimming for their critical reading of the manuscript and A. Hendrich for assembling the synoptic chart.

Dr. M. Menning is with the Zentralinstitut für Physik der Erde (ZIPE, Telegrafenberg, Potsdam, Post Potsdam, D.D.R. 1561). A graduate of the Ernst-MoritzArndt-Universität Greifswald, he now carries out research in magnetostratigraphy and time analysis of late Palaeozoic sequences and their tectonic implications. He is interested in interdisciplinary cooperation for the calibration of the Phanerozoic time scale.

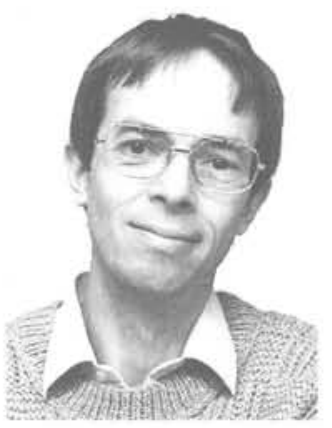

\section{References}

Afanasyev, G.D. et al., 1964. Geochronological time-scale in absolute chronology. Soviet Contributions to the 22 International Geological Congress, India, p. 287-324, (in Russian).

Afanasyev, G.D. and Zykov, S.1., 1975. Phanerozoic Geochronological Time Scale in Light of Significantly New Deeay Constants. Nauka, Noscow, 100p., (in Russian).

Afanasyev, S.L., 1987. Phanerozoic Geochronological Scale and the Problem of Geological Time. Nedra, Moseow, 144p., (in Russian).

Anderson, J.M., 1981. World Perao-Triassic correlations: Their biostratigraphic basis In: Cressuetell, It. Gondwana Symposium, Wellington 1980, BnIke-ma, Rotterdam, p. 3-17,

Armstrong, R.L., 1978. Pte-Cenozoic Phanerozoic Time scale - computer file of critical dates and consequences of new and in-progress decay-constant revisions in: Cohee, G.V., Glaessner, Y.F. and Hedters, H.D. (eds.), Contributions to the Geological Time Seale, American Association of Petroleura Geologists, Studies in Geology, no. 6, p. $73-91$.

Barrell, J., 1917. Rhythms and the measurements of geologic time. Geologieal Society of America Bulletin, v. 28, p. 745-904.

Bayer, U. 1987. Chronomet ric calibration of a comparative time seale for the "fesozoic and Paleozoie. Geolozische Rundsehau, v. 76, no. 2, p. 485-503.

Benkö, F., 1985. Geological and Cosmogenie Cyeles as Reflected by the New Law of Universal Cyclicity. Akadémai Kiardo, Budapest, $401 \mathrm{p}$.

Bergeren, W.A., Kent, D.V., Flynn, J.J. and van Couvering, J.A., 1985. Cenozoic geochronology. Geological Society of Ameriea Bulletin, v. 96, no. 11. p. 1407-1418.

Bouroz, A., 1978. Beport on isotopie dating of rocks in the Carboniferous System. In: Cohee, G.V. et al. (eds), Cont ributions to the Geolozic Time Scale. Americun Association of Aetroleum Geologists, Studies in Gienlogy, no. 6, p. 323-326.

Bubnoff, S. von, 1947. Rhythmen, Zyklen und Zeitrechnurg in der Geologie. GeologIsehe Rundsehau, v. 35, p. 6-22.

Burke, W.H., et al, 1982. Variation of seawater ${ }^{87} \mathrm{Sr} / 86 \mathrm{Sr}$ throughout Phanerozole time. Geology, v. 10, D. $516-519$

Carr, P.F., Jones, B. S., Quinn, 9., and 'iright, A.J., 1984 . Toward an objective Phanerozoic time seale. Geology, v. 12, no. 5, p. 274-277.

Cloud, P., 1987. Trends, transitions and events in Cryptozoie history and their ealibration: Apropos recommendations by the Subeommission on Precambrian Stratigraphy. Precambeian Research vo 37 , no, 3, P. $257-265$.

Cowie, J.W. and Cribb, S.J., 1978. The Cambrian System. In: Cohee, G.V. et al. (eds.), Contributions to the Geologic Time Scale. American Association of Petroleum Geologists, Studies in Geology, v. 6, p. 355-362.

Cowie, J.W., Zeigler, W., Boucot, A.J., Bassett, "1.G. and 'Gemane, J., 1986, Guidetines and statutes of the International Commission of Stratigraphy (ICS). Courier Forschungsinstitut Senckenberg, Frankfurt-am-Main, v. 83, $14 \mathrm{p}$.

Dunbar, C.O. et al., 1960. Correlation of the Pertwian formations of North Ameriea. Geological Society of American Bulletin, v. 71, p. 1763-1805.

Echelle Synthétique, 1966. Reproduced in Internationale Kommission für Geochronologie, 1968. Vengleichende. Table det nuvesten veröffentlichen geochronologisehe Skalen für die Zeiten des Phanerozoikuns. Geologit-Zeitschrift für das Gesamtgebiet der Geologischen Wissenschaften, v. 2, no. 2, p. 210-215,

Forster, S.C. and Warrington, G., 1985. Geochronology of the Carboniferous, Permian and Triassic. In: Snelling, N.J. (ed.), The Chronology of the Geological Record, The Geological Society of London, Hemoir No. 10. Blackwell Selentific Publications. p. 99-113.

Gordon, M., Jr. and Mamet, B.L., 1978. The "tississippian-Pennsylvanian Boundary. In: Cohee, Give Association of Petroleum Geologists, Sturties in Geology, v, 6, p. 327-335.

Gregor, C.B., 1985. The mass-age distribution of Phanerozolc sediments In: Snelling. N.J. (ed.). The Chronology of the Geological Record. The Geologieal Society of Lonfon, Mtemoir No, 10, Blackwell Scientific Publications. P, 284-289.

Haq, B.U. and Van Eysingr, F.W.B., 1987. Geological Time Table. Fourth revised enlarged and updated edition. Elsevier Sclence Aublishers B.V., Amsterdami.
Harland, W.B., Cox, A.V., Lewellyn, P.G., Pckton, C.A.G., Smith A.G, and Walters R., 1982. Geological Time Seale. Cambridge University Press, Cambridge, 131 p.

Harlanc, W.B., Smith, A.G, and Wilcock, B. (eds.), 1964. The Phanerozoic time-scale. (A symposium dedicated to Professor Arthur Holmes). Quarterly Journal Geological Society of l.ondion v. $120 \mathrm{~s}, 458 \mathrm{p}$.

Hedberg, H.D. (ed.), 1976. International Stratigraphic Guide. John Wiley \& Sons, New York, 200p.

Hellmann, K.N. and Lippolt, H.J., 1981. Calibration of the Middle Triassie time scale by conventional $\mathrm{K}-\mathrm{Ar}$ and $40 \mathrm{Ar} / 39 \mathrm{Ar}$ dating of alkali feldspars Journal of Geophysies, Berlin, v. 50, p. 73-88.

Hess, J.C. and Lippolt, J.H., 1986. ${ }^{40} \mathrm{Ar} /{ }^{39} \mathrm{Ar}$ ages of tonstein and tuff sanidines: New calibration points for the improvement of the Upper Carboniferous time scale. Chemical Geology (Isotope Geoscience Section), v. 59, no. 2/3, p. 143-134.

Holmes, A., 1937. The age of the Earth (new edition, revised and rewritten). Nelson, L.ondon, $263 \mathrm{p}$.

Holmes A., 1947. The eonstruction of a geological time-seale. Transactions Geological Society Glasgow, v. 21, p. 117-152.

Holmes, A., 1959. A revised geological time seale. Transactions Edinburgh Geological Society, v, 17, D, 183-216.

Jaeger, H., 1980. Silurian series and stages: a comment. Lethaik, v. 13, p. 365.

Kaemmel, T., 1986. Zur Entwieklung und Anwendung der radiogeochronologischen Skala des Phanerozolkums Zeitschrift Geologisehe ivissensehaften, 8,14, no, 5, p. 593-606.

Kent, D.V. and Gradstein, F.M.. 1985. A Cretaceous and Jurassic geochronology. Geological Society of America Bulletin, v. 96, no. 11, p, 1419-1427.

Kozur, H., 1980. Beit räge zur Stratigraphie des Perms, Teil III (2): Zur Korrelation der uberwiegend kontinentalen Ablagerungen des obersten Karbons and Aurms von Mittel und Westeuropa. Freiberger Forsehungshefte, Lelpzig, v. C348, p. 69-172.

Kulp, J.L., 1961. Geological Time Seale. Seience, v. 133, no. 3459, p. 1105-1114.

LaBrecque, J.L., Kent, D.V. and Cande, S.C., 1977. Revised magnetic polarity time scale for late Cretaceous and Cenozoic time. Geology, v. 5, no. 6, p. 330-335.

Lambert, R.St.J., 1971. The pre-Pleistocene Phanerozoic time-seale - further data. In: Harland, w.B. et al. (erts.), The Phanerozole time-scale - a supplement. Geological Society of London, Special Publication no. 5, p. 9-34.

Likharev, B.K. (ed.), 1966. The A.rmian system. Nedra, Lloscow, 536p., (in Russian).

Lippolt, H.J., Hess, J.C. and Burger, K., 1984. Isotopisehe Alter von pyroklastisehen Sanidinen aus Kaolin Kohlentonsteinen ale Korrelationsmarken für das mittel europïische Oberkarbon. Fortschritte der Geologite von Rheinland und ivestfalen, krefeld, v. 32, p. 119-150.

Mekerrow, W.S., Lambert, R.St.J. and Chamberlain, V.E., 1980. The Ordovieian, Silurian and Devonian time seales. Earth and Panetary Science Letters, v. 51, no. 1, p. 1-8.

Menning, M., 1986. Zur Dauer des Zechsteins aus magnetostratigraphiseher Sieht. Zeltschrift Geolozisehe Wissensehaften, v. 14, no. 4, p. 395-404.

Menning, M., 1989. Zapid subsidence in the Central European Basin during the initial development (A.rmian-Triassie boundary sequences, 258-240 $\mathrm{Ma}$ ). Zentralblatt für Geologie und Paläontologie, Stuttgart.

Ddin, G.S. (ert.), 1982n. Numerieal Dating in Stratigraphy. John Wiley and Sons Chichester, Part 1, p. 1-630, Part 2, p. 533-1040.

Odin, G.S., 1982t. The Phanerozoic time seale revisited. Episodes, v. 1982, no. 3, D. 3-9.

Odin, G,S, 1986, Recent advances in Phanerozoic time-scale calibration. In: Odin, GiS., Calibration of the Pranerozoie Time Scale, Chemieal Geology (Isotope Geoscience Section), v. 59, no. 2/3, p. 103-110.

Palmer, 4.R., 1983. The Decade of North American Geology 1983 Geolozic Time Scale. Gitology, v. 11, no. 9, p. 503-504.

Plot, J. and Rösler, H.J., 1967. Altersbestimuming von Kalisalzmineralen. Natur wissenschaften, v. 54, p. 490.

Goss R.J. and Naeser, Ch.W., 1984. The Orfovician time seale - new refinements, In: Beuton, D.L. (erf,), Aspects of the Orfovicinn System, Balneontological Contributions of the University of Osio, v. 295 , p. 5-10.

Salvador, A., 1985. Chronostratigmphic and Geochronometrie Seales in COSUNA Stratigraphic Correlation charts of the United States. American A ssociation of Petroleum Cieologists Bullet in, vo 69 , no, 2, p. $181-189$.

Shell, 1980. Standand legend, time stratigraphic table. Shell International Petroleum Yastschappij, The Hague.

Snelling, N.J. fert), 1985a. The Chronology of the Geologieal Record, The Geologica Society of London, Hentoir No, 10. Blackwell Scientific Publieations, p. 261-265.

Snelling, N.J., 1985b. An interim time-scale. in: Snelling, N.J. (ed.), The Chronology of the Geological Recom, The Gieolozical Society of London, Memoir No. 10. Blackwell Seientific Publications, p. 261-265.

Steiger, ?.H. and Jäger, E., 1977 . Subcommission on Geochronology: Convention on the use of decay constants in Be- and cosmochronology. Farth and Planetary Seience Letters, v. 36, p. 359-362.

Stille, H., 1924. Grundfragen der vergleichenden Tektonik. Gebrbrüder Bornt räger, Berlin, vili, 443 p.

Vail, P.R. and Mitchum, R.2T., Jr., 1977. Seismic stratigraphy and global changes of sea level, Part 1: Overview. In: Payton, C.E. (ed.), Seismic stratigraphy - applications to hydrocarbon exploration. American Association Pet roleum Geologists, p. 51-52.

Van Eysinga, F.W.B., 1975. Geological Time Table. (chart) Elsevier, Amsterdam, 3rd edition.

Van IIinte, J.E., 197.6. A Jurassic time scale. American Association of Petroleun Geologists Bulletin, v. 60 , no. 4, p. 498-51 6 .

Webb, J.A., 1981. A radiometric time scale of the Triassic. Journal of the Geological Society of Australia, Sydney, v. 28, p. 107-121. 